\title{
Simultaneous Cranioplasty and External Ventricular Drain Implantation in Patients with Hydrocephalus: Case Series and Literature Review
}

\section{Implante de derivação ventricular externa e cranioplastia simultânea em pacientes com hidrocefalia: Série de casos e revisão de literatura}

Lívio Pereira de Macêdo $^{1}$ Arlindo Ugulino Netto ${ }^{1}$ Kauê Franke ${ }^{1}$ Pierre Vansant Oliveira Eugenio ${ }^{2}$ John Anderson da Silva Rocha ${ }^{1}$ Glaudir Donato Pinto Júnior ${ }^{2}$ João Pedro Maia Medeiros ${ }^{2}$ Juan Pablo Borges Rodrigues Maricevich ${ }^{3}{ }^{\circledR 0}$ Nivaldo S. Almeida ${ }^{1} \quad$ Hildo Rocha Cirne Azevedo-Filho ${ }^{10}$

${ }^{1}$ Department of Neurosurgery, Hospital da Restauração, Recife, Pernambuco, Brazil

${ }^{2}$ Centro de Ciências Médicas, Universidade Federal da Paraíba, João

Address for correspondence Lívio Pereira de Macêdo, MD, Rua João Fernandes Vieira, 544, Boa Vista, Recife, PE, 50050-200, Brazil

Pessoa, Paraíba, Brazil

${ }^{3}$ Department of Plastic Surgery, Hospital da Restauração, Recife,

Pernambuco, Brazil

Arq Bras Neurocir 2021;40(4):e297-e302.
Abstract
Keywords
- cranioplasty
- external ventricular drain
- post-traumatic hydrocephalus
- neurosurgery

Introduction The increase in intracranial pressure (ICP) is a neurological complication resulting from numerous pathologies that affect the brain and its compartments. Therefore, decompressive craniectomy (DC) is an alternative adopted to reduce ICP in emergencies, especially in cases refractory to clinical therapies, in favor of patient survival. However, DC is associated with several complications, including hydrocephalus (HC). The present study presents the results of an unusual intervention to this complication: the implantation of an external ventricular drain (EVD) in the intraoperative period of cranioplasty (CP).

Methods Patients of both genders who presented with $\mathrm{HC}$ and externalization of the brain through the cranial vault after decompressive hemicraniectomy and underwent EVD implantation, to allow the CP procedure, in the same surgical procedure, were included.

Results Five patients underwent DC due to a refractory increase in ICP, due to automobile accidents, firearm projectiles, falls from stairs, and ischemic strokes. All evolved with HC. There was no uniform time interval between DC and CP. The cerebrospinal fluid (CSF) was drained according to the need for correction of cerebral received

October 18, 2020

accepted

January 00, 2021

published online

July 29, 2021
DOI https://doi.org/

10.1055/s-0041-1730332. ISSN 0103-5355.

\footnotetext{
(c) 2021. Sociedade Brasileira de Neurocirurgia. All rights reserved. This is an open access article published by Thieme under the terms of the Creative Commons Attribution-NonDerivative-NonCommercial-License, permitting copying and reproduction so long as the original work is given appropriate credit. Contents may not be used for commercial purposes, or adapted, remixed, transformed or built upon. (https://creativecommons.org/ licenses/by-nc-nd/4.0/)

Thieme Revinter Publicações Ltda., Rua do Matoso 170, Rio de Janeiro, RJ, CEP 20270-135, Brazil
} 


\begin{abstract}
Resumo
Palavras-chave

- cranioplastia

- dreno ventricular externo

- hidrocefalia póstraumática

- neurocirurgia

Introdução O aumento da pressão intracraniana (PIC) decorre de inúmeras patologias que acometem o encéfalo e seus envoltórios. Diante disso, a craniectomia descompressiva (CD) é uma alternativa adotada para redução da PIC nas emergências, especialmente em casos refratários a terapias clínicas, em prol da sobrevida dos pacientes. Entretanto, existem diversas complicações associadas à $C D$, entre as quais está a hidrocefalia (HC). O presente estudo apresenta resultados de uma intervenção incomum para essa complicação: o implante de derivação ventricular externa (DVE) no intraoperatório de cranioplastia (CP).

Métodos Foram incluídos pacientes de ambos os gêneros que apresentaram HC e exteriorização encefálica da abóbada craniana após hemicraniectomia descompressiva e foram submetidos a implante de DVE, para possibilitar a CP, no mesmo ato operatório.

Resultados Cinco pacientes foram submetidos a CD pelo aumento refratário da PIC, decorrente de acidentes automobilísticos, projéteis de arma de fogo, quedas de escada e acidentes vasculares cerebrais isquêmicos. Todos evoluíram com HC. Não houve uniformidade de intervalo de tempo entre a CD e a CP. O líquido cerebroespinal (LCE) foi drenado de acordo com a necessidade de correção da herniação cerebral em cada paciente, antes da CP. Todos os pacientes evoluíram bem, sem déficits neurológicos no pós-operatório imediato.

Conclusão Ainda existem inúmeras incertezas sobre o manejo da $\mathrm{HC}$ consequente de CD. Assim, outras estratégias de CP simultânea à drenagem de LCE, não necessariamente relacionadas à derivação ventriculoperitoneal, devem ser consideradas e avaliadas mais profundamente, tendo em vista a constatação de eficácia em procedimentos desse âmbito, como a DVE abordada no presente estudo.
\end{abstract}

herniation in each patient, before undergoing cranioplasty. All patients progressed well, without neurological deficits in the immediate postoperative period.

Conclusion There are still several uncertainties about the management of $\mathrm{HC}$ resulting from DC. In this context, other $\mathrm{CP}$ strategies simultaneous to the drainage of CSF, not necessarily related to ventriculoperitoneal shunt (VPS), should be considered and evaluated more deeply, in view of the verification of efficacy in procedures of this scope, such as the EVD addressed in this study.

\section{Introduction}

The increase in intracranial pressure (ICP) is a neurological complication resulting from numerous pathologies that affect the brain and its compartments, including intracranial factors, like expansive mass lesions - such as tumors and hematomas -, or extracranial events - such as hyponatremia, hypotension, and hypoxia. ${ }^{1}$

Decompressive craniectomy (DC) is a surgical procedure adopted in emergencies as an alternative to reduce ICP, especially in cases refractory to clinical therapies, in order to improve patient survival. ${ }^{2}$ However, DC is associated with several complications, which can develop quickly - such as hemorrhages, extracranial brain herniations, cerebrospinal fluid fistulas, postoperative infections, convulsions - or later, such as subdural hygromas, motor trephine syndrome, and hydrocephalus $(\mathrm{HC})^{2}$
Regarding HC after DC, it can be said that this is a common complication, with an incidence of 0.7 to $86 \%$ of cases, depending on the diagnostic criteria, ${ }^{3,4}$ so that $\sim 8$ to $11 \%$ of the patients need a measure of therapeutic intervention. ${ }^{4}$

One of the ways to manage the HC developed after DC is to perform the implantation of a ventriculoperitoneal shunt (VPS) followed by the definitive cranioplasty (CP). This conduct can be carried out simultaneously or in two programmed stages, with experiences varying according to each center. $^{5}$

Thus, the present study aims to add to the literature on the topic of the descriptive presentation of the results of an unusual surgical method: the implantation of an external ventricular drain (EVD) for the management of consecutive $\mathrm{HC}$ of decompressive hemicraniectomy in the transoperative of $\mathrm{CP}$, which evolved with a positive prognosis in a series of five patients. 
Table 1 Clinical profile, etiology, initial complication, time elapsed between decompressive craniectomy and cranioplasty and volume of cerebrospinal fluid drained in the external ventricular drain of the reported patients

\begin{tabular}{|l|l|l|l|l|l|l|}
\hline Patient & Gender & $\begin{array}{l}\text { Age } \\
\text { (yyearold) }\end{array}$ & Etiology & $\begin{array}{l}\text { Initial } \\
\text { complication }\end{array}$ & $\begin{array}{l}\text { Volume of CSF } \\
\text { drained in the EVD }\end{array}$ & $\begin{array}{l}\text { Time elapsed between } \\
\text { DC and CP }\end{array}$ \\
\hline 1 & M & 24 & $\begin{array}{l}\text { Motorcycle } \\
\text { accident }\end{array}$ & ASDH & $650 \mathrm{~mL}$ & 18 months \\
\hline 2 & M & 27 & FAP & ASDH & $200 \mathrm{~mL}$ & 38 months \\
\hline 3 & M & 33 & FFS & ASDH & $150 \mathrm{~mL}$ & 30 months \\
\hline 4 & M & 40 & IS & CE & $150 \mathrm{~mL}$ & 54 months \\
\hline 5 & F & 48 & IS & CE & $150 \mathrm{~mL}$ & 17 months \\
\hline
\end{tabular}

Abbreviations: ASDH, acute subdural hematoma; CE, cytotoxic edema; CP, cranioplasty; CSF, cerebrospinal fluid; DC, decompressive craniectomy; EVD, external ventricular drain; F, female; FAP, firearm projectile; FFS, fall from stairs; IS, ischemic stroke; M, male.

\section{Methods}

This is an observational, cross-sectional and descriptive study of patients seen at the Neurosurgery Department of the Hospital da Restauração, Recife, PE, Brazil, from February 2016 to October 2019.

Patients of both genders who presented HC and externalization of the brain through the cranial vault after decompressive hemicraniectomy and underwent EVD implantation, to allow the $\mathrm{CP}$ procedure, in the same surgical procedure, were included. Patients who did not meet the inclusion criteria were excluded.

All patients and relatives involved filled out a consent form, authorizing participation in the present study, as well as disclosure to the scientific community.

The cases were evaluated regarding sex, age, etiology, initial complication, time elapsed between the DC and the $\mathrm{CP}$, and the volume of cerebrospinal fluid (CSF) drained in the EVD. This information is summarized in - Table 1.

The reconstruction of the skullcap was guided by a customized three-dimensional (3D) technique, using polymethylmethacrylate (PMMA). ${ }^{6-9}$ After CP, the EVD was closed and removed in an interval of 24 to 48 hours, with the patient still in the intensive care unit (ICU).

An integrative literature review on the topic was developed, seeking to relate the scientific discussion to the findings of the present study. The research was conducted in the PubMed platform, using the descriptors decompressive craniectomy AND hydrocephalus, and cranioplasty AND external ventricular drain.

\section{Results}

A total of 5 patients, 4 (80.0\%) males and 1 (20.0\%) female, whose ages ranged from 24 to 48 years old, with a median of 33 years old, underwent DC due to refractory increase of the PIC. The etiologies of this entity were automobile accidents, firearm projectiles, falls from stairs, and ischemic strokes.

As an initial complication, the victims of traumatic brain injury developed acute subdural hematoma, and the cases of stroke involved cytotoxic edema, both with increased ICP refractory to clinical therapies. After undergoing DC, all patients developed HC in the postoperative period.
For the management of post-DC HC, an EVD was implanted in the same surgical procedure that the CP was performed. Between 150 and $650 \mathrm{ml}$ of cerebrospinal fluid (CSF) was drained, according to the need for correction of cerebral herniation in each patient, before undergoing cranioplasty. The time elapsed between the DC and the CP ranged from 17 to 54 months, with an average of 31.4 months, with no uniformity in this interval.

All patients evolved well, without neurological deficits in the immediate postoperative period, and were referred to routine outpatient follow-up (-Figs. 1-5).

\section{Discussion}

In the emergency environment, DC has consolidated itself as an effective measure to decrease the ICP, which rises due to several scenarios, such as infections, tumors, hemorrhages,

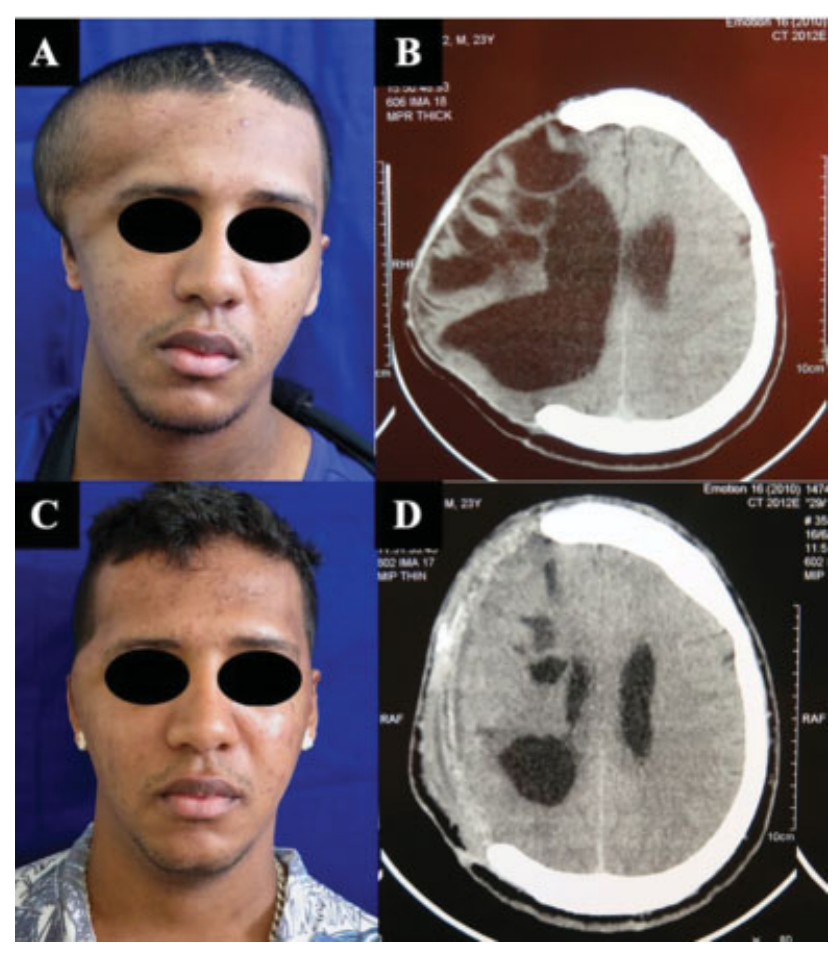

Fig. 1 Patient 1. Comparatively, the visual and tomographic aspects of the pre- $(A, B)$ and postoperative $(C, D)$ of the EVD. 


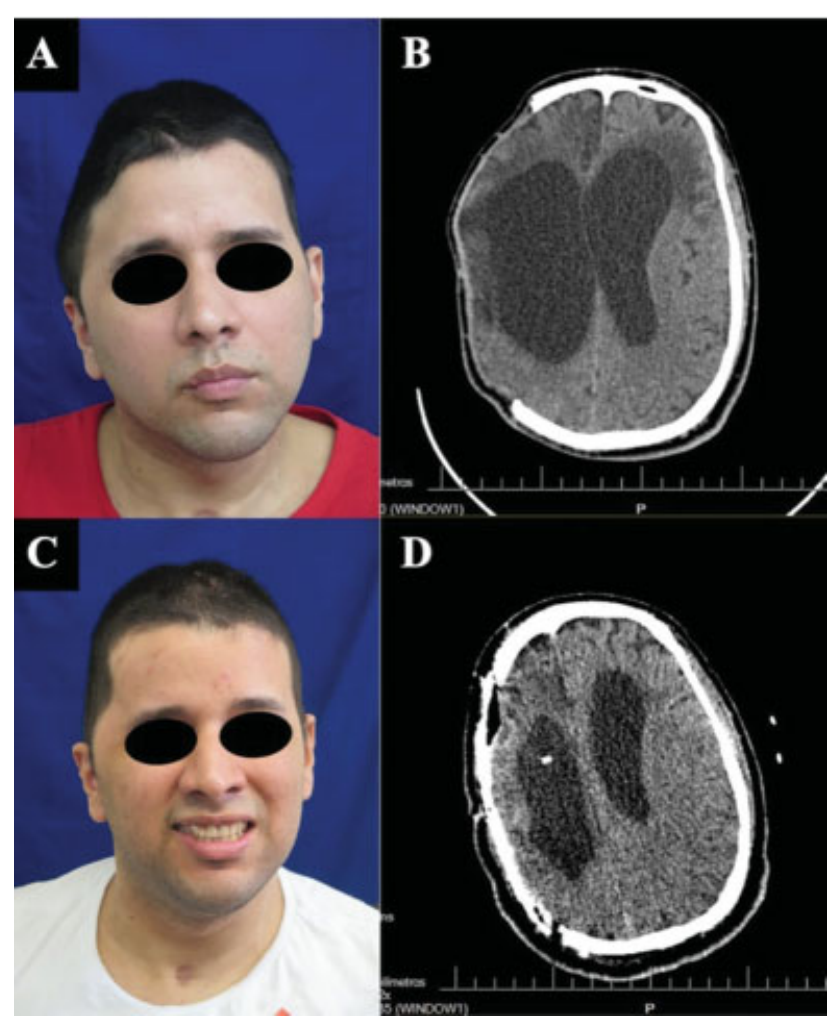

Fig. 2 Patient 2. Comparatively, the visual and tomographic aspects of the pre- $(A, B)$ and postoperative $(C, D)$ of the EVD.

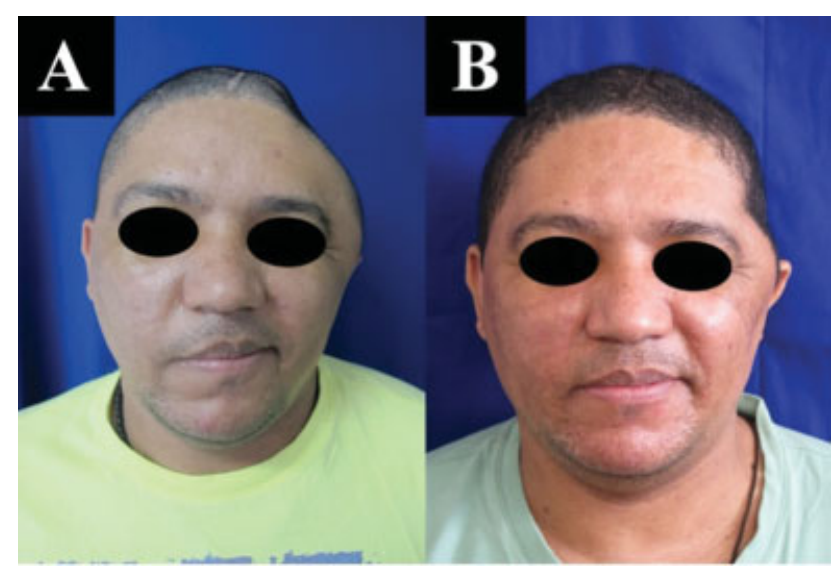

Fig. 3 Patient 3. Comparison of the pre- (A) and postoperative (B) visual aspect of the EVD followed by $\mathrm{CP}$, in view of the $\mathrm{HC}$ developed after decompressive craniotomy.

strokes, and traumatic brain injuries. ${ }^{1,2,10-12}$ In this procedure, the opening of the cranial vault and of the dura mater allows the distribution of the brain component, relieving the ICP and favoring patient survival. ${ }^{2,10-12}$

However, like any other surgical procedure, DC is not free of possible complications. In this regard, progressive neurological decline can be mentioned, ${ }^{10,13}$ in addition to hemorrhages, infections, inflammations and, also, disorders of the ventricular system, ${ }^{14}$ where the CSF flows. Among the latter complications, there is $\mathrm{HC}$, which, according to the literature, is triggered by changes in pulse wave pressure through the

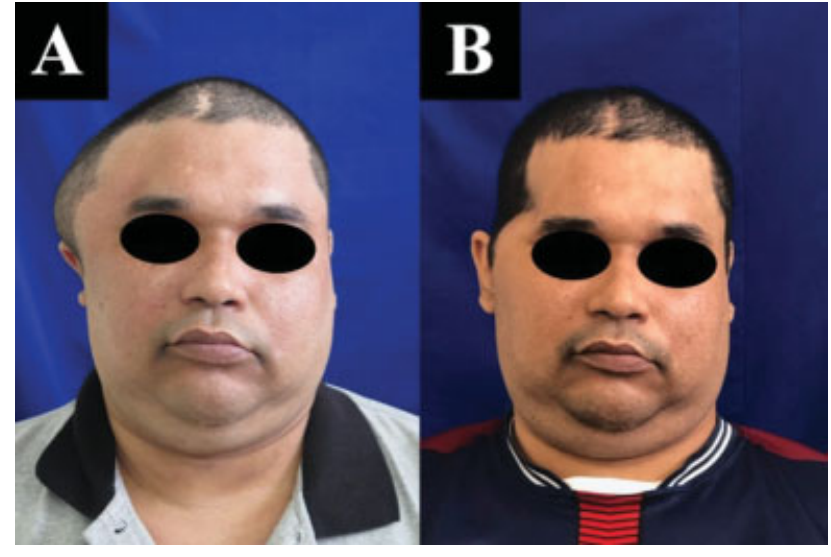

Fig. 4 Patient 4. Comparison of the pre- (A) and postoperative (B) visual aspect of the EVD followed by $C P$, in view of the $H C$ developed after decompressive craniotomy.

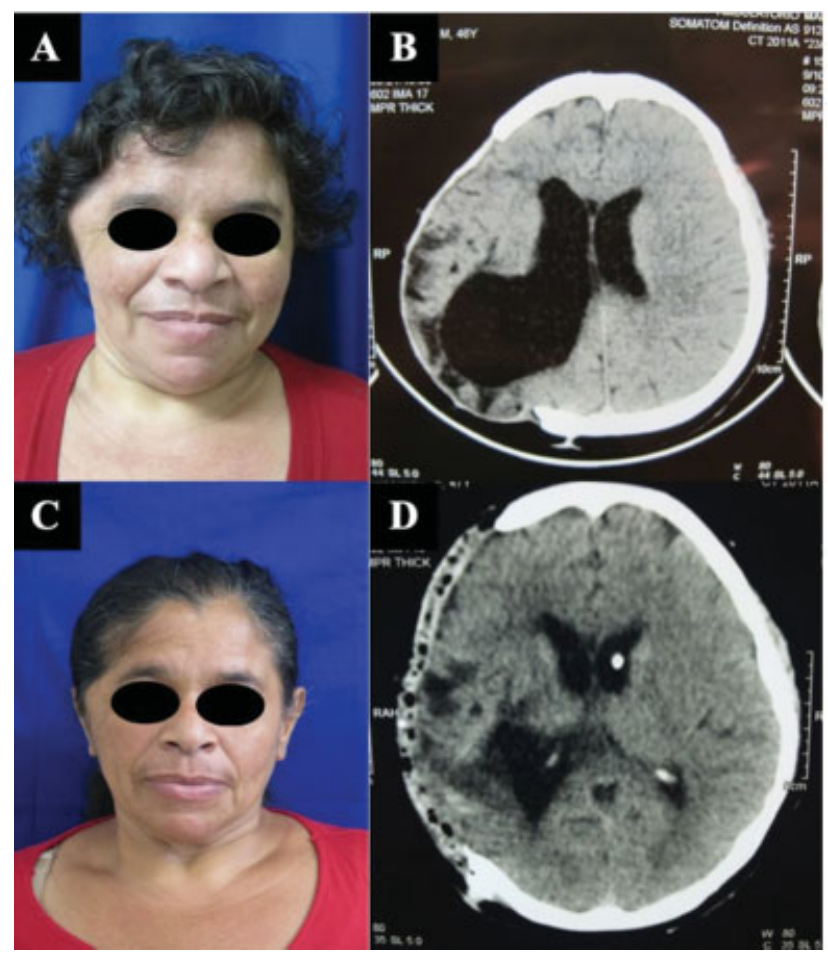

Fig. 5 Patient 5. Comparatively, the visual and tomographic aspects of the pre- $(A, B)$ and postoperative $(C, D)$ of the EVD.

convexity of the brain ${ }^{15,16}$ and by a reduction in venous flow in the medial margin of the craniectomy. ${ }^{16-18}$ Some studies also point to the extension of the craniectomy as a predisposing factor for $\mathrm{HC}^{4,16,18,19}$

The HC developed after DC has a very variable incidence rate, according to scientific studies, in view of the difference in the criteria adopted by the centers for diagnosing this condition. ${ }^{3,4}$ Some authors consider necessarily the clinical manifestations of $\mathrm{HC}$, while others only analyze the expanded ventricular morphology by computed tomography (CT), converging on the concept of ventriculomegaly. ${ }^{16,17,20}$

In view of the post-DC HC, $\sim 1$ in 10 cases requires intervention. $^{4,14}$ In this scenario, $\mathrm{CP}$ is discussed as an 
alternative for a better prognosis for patients, considering the therapeutic potential ${ }^{21-23}$ and neurological recovery, ${ }^{21,22}$ as well as the aesthetic advantage. ${ }^{23}$ However, some authors claim that there are still no strong scientific correlations between cranioplasty and better neurological results. $^{23}$

Regarding CP, moreover, it is known that there is a predisposition to other complications, especially after DC. ${ }^{12,14,21,23}$ Among these complications, in addition to those associated with the postoperative period of DC, the possible impasses linked to the consolidation of the bone flap are added. ${ }^{14}$ In this sense, the scientific community debates strategies to mitigate these obstacles, analyzing issues such as the clinical conditions of the patients and their comorbidities, the method of preservation of the bone flap, the material used for cranial reconstruction, the moment when $\mathrm{CP}$ should be indicated, and the surgical technique addressed. $^{10,21,23}$

Regarding the profile of the patients (age, sex, presence of comorbidities, clinical history), preservation of the bone flap, and the material used for $\mathrm{CP}$, the studies did not find associations with greater risk of complications. ${ }^{10,21,23}$ However, the use of autologous bone - which is more common, especially in centers with less resources - seems to be related to higher probabilities of bone flap resorption and implant failure when compared with heterologous materials. ${ }^{23}$

For the procedures of the present study, in fact, the diversity of patient profiles did not imply different predispositions to possible risks. As for the material adopted in the plastic surgery, the customized PMMA prosthesis was chosen, by $3 \mathrm{D}$ printing - due to the accessibility and reproducibility of the technique, in addition to the therapeutic and aesthetic results -, according to the experience with these operations of our center. ${ }^{6-9}$

There is also no consensus on the appropriate time for $\mathrm{CP}$ intervention. On the one hand, there are a number of studies that associate late reconstruction with unfavorable results. $^{2,12,20,23}$ In view of this, there are authors who suggest using a period of $\sim 2$ weeks after DC as a reference, when, generally, cerebral edema can already be seen exteriorizing the cranial vault by $\mathrm{CT}$, which is compatible with the clinical examination of the patient during this period. ${ }^{20,23}$ Other researchers also point to a period of up to 12 weeks after craniectomy, in order to avoid the need for new interventions. ${ }^{2}$ On the other hand, there are several other evidence that contradict this aspect. Within this controversy, the systematic review developed by De Cola et al. indicated that an interval of 3 to 6 months between DC and CP is favorable to better motor and cognitive recoveries. ${ }^{24}$

Regarding the surgical technique, $\mathrm{CP}$, by itself, is already presented as a therapeutic approach, and is even considered sufficient, in the circumstances in which the brain is flaccid. $^{25-27}$ There are even reports in the literature of patients in whom the mechanism of deviation of CSF proved to be unnecessary. ${ }^{22}$ However, in conditions of tension and brain herniation, CSF drainage may be required, ${ }^{16}$ correcting the exteriorization of the brain and enabling the reconstruction of the skull. About these situations, there is a wide discussion in scientific studies as to the most effective and safe ventricular drainage conduct.

Regarding the VPS derivation strategy, commonly performed in various centers, there are several articles that associated $\mathrm{CP}$ in the same operative act as this procedure as a factor for obtaining complications - such as infection and bone resorption -, suggesting intervention in stages as most appropriate. ${ }^{5,28-30}$ Despite this, a study showed positive evaluations of a "single-stage surgical technique with temporary occlusion of the distal shunt catheter", associated with a slow reduction in the pressure of the programmable VPS valve. ${ }^{31}$

The effectiveness of using the programmable VPS technology in the management of CP after DC is reiterated by other authors, ${ }^{25,31-33}$ especially when compared with the permanent VPS, which may even involve excessive drainage and subdural collections. ${ }^{16,34}$ However, this is an expensive approach and, therefore, inaccessible to the socioeconomic conditions of most patients. ${ }^{16}$ Still, as an alternative for performing simultaneous $\mathrm{CP}$ to the management of postDC HC, a study obtained better results from simultaneous ventriculostomy to $\mathrm{CP}$, followed, in a few days, by the implantation of VPS. ${ }^{25}$

On the other hand, considering the impasses related to the use of permanent shunt, for patients who need CSF drainage in the act of $\mathrm{CP}$, the temporary lumbar or ventricular drainage presented themselves as valid and effective strategies. ${ }^{16,22}$ Performing an aspiration procedure at the $\mathrm{CP}$, the study by Kutty et al. could avoid the use of VPS in 10 of 11 patients with ventriculomegaly due to DC, with therapeutic success. ${ }^{16}$ Following this trend, the execution of EVD in the intraoperative period of $\mathrm{CP}$, through the $\mathrm{HC}$ developed after DC, draining CSF according to the need to correct cerebral herniation, proved to be a viable alternative.

\section{Conclusion}

The scientific community still deals with countless uncertainties about the conduct of intervention to $\mathrm{HC}$ resulting from DC. Despite this, studies have already found the effectiveness of $\mathrm{CP}$, either alone or associated with a method of draining CSF, when necessary. There is a requirement for drainage by thorough technique, such as programmable VPS, in the search to avoid further complications. However, this procedure requires resources that are inaccessible to most patients.

Studies on the use of permanent VPS reveal other risks linked to this conduct, such as excessive drainage and subdural collections. Furthermore, the indication of the procedure, in stages, using VPS, requires the performance of more than one surgical act and, therefore, a constant monitoring of the clinical evolution of the patient to mitigate the impasses of these interventions.

Hence, other CP strategies simultaneous to the management of post-DC HC, not necessarily related to VPS, should be considered and evaluated more deeply, in view of the verification of the effectiveness in procedures of this scope, such as the EVD addressed in this study. 


\section{Conflict of Interests}

The authors have no conflict of interests to declare.

\section{References}

1 Stocchetti N, Maas AIR. Traumatic intracranial hypertension. N Engl J Med 2014;370(22):2121-2130

2 Gopalakrishnan MS, Shanbhag NC, Shukla DP, Konar SK, Bhat DI, Devi BI. Complications of decompressive craniectomy. Front Neurol 2018;9:977. Doi: 10.3389/fneur.2018.00977

3 De Bonis P, Sturiale CL, Anile C, et al. Decompressive craniectomy, interhemispheric hygroma and hydrocephalus: a timeline of events? Clin Neurol Neurosurg 2013;115(08):1308-1312. Doi: 10.1016/j.clineuro.2012.12.011

4 Choi I, Park HK, Chang JC, Cho SJ, Choi SK, Byun BJ. Clinical factors for the development of posttraumatic hydrocephalus after decompressive craniectomy. J Korean Neurosurg Soc 2008;43 (05):227-231

5 Schuss P, Borger V, Güresir Á, Vatter H, Güresir E. Cranioplasty and Ventriculoperitoneal Shunt Placement after Decompressive Craniectomy: Staged Surgery Is Associated with Fewer Postoperative Complications. World Neurosurg 2015;84(04):1051-1054

6 Pereira de Macêdo L, Netto AU, Maricevich JPBR, Almeida NS, Azevedo-Filho HRC, et al. Ventriculoperitoneal shunt occlusion and cranioplasty: A case report. Romanian Neurosurgery 2020;34 (03):405-410. Doi: 10.33962/roneuro-2020-063

7 Maricevich JPBR, Cezar AB, de Oliveira EX, Silva JAMVE, Maricevich RS, Almeida NS, Azevedo-Filho HRC, et al. Adhesion sutures for seroma reduction in cranial reconstructions with polymethyl methacrylate prosthesis in patients undergoing decompressive craniectomy: A clinical trial. Surg Neurol Int 2018 Aug 22;9:168. Doi: 10.4103/sni.sni_102_18

8 Maricevich JPBR, Cezar-Junior AB, de Oliveira-Junior EX, et al. Functional and aesthetic evaluation after cranial reconstruction with polymethyl methacrylate prostheses using low-cost 3D printing templates in patients with cranial defects secondary to decompressive craniectomies: A prospective study. Surg Neurol Int 2019 Jan 15;10:1. Doi: 10.4103/sni.sni_149_18

9 Maricevich P, Campolina AC. Skull reconstruction with PMMA customized prostheses after decompressive craniectomies. Rev. Bras. Cir. Plast 2017;32(01):46-55

10 Sobani ZA, Shamim MS, Zafar SN, Qadeer M, Bilal N, Murtaza SG, Enam SA, Bari ME, et al. Cranioplasty after decompressive craniectomy: An institutional audit and analysis of factors related to complications. Surg Neurol Int 2011;2:123. Doi: 10.4103/21527806.85055. Epub 2011 Sep 17.

11 Fattahian R, Bagheri SR, Sadeghi M. Development of Posttraumatic Hydrocephalus Requiring Ventriculoperitoneal Shunt After Decompressive Craniectomy for Traumatic Brain Injury: a Systematic Review and Meta-analysis of Retrospective Studies. Med Arch 2018 Jun;72(03):214-219. Doi: 10.5455/medarh.2018.72.214-219

12 Nasi D, Dobran M, Di Rienzo A, et al. Decompressive Craniectomy for Traumatic Brain Injury: The Role of Cranioplasty and Hydrocephalus on Outcome. World Neurosurg 2018;116:e543-e549. Doi: 10.1016/j.wneu.2018.05.028

13 Yamaura A, Makino H. Neurological deficits in the presence of the sinking skin flap following decompressive craniectomy. Neurol Med Chir (Tokyo) 1977;17(1 Pt 1):43-53

14 Kurland DB, Khaladj-Ghom A, Stokum JA, et al. Complications Associated with Decompressive Craniectomy: A Systematic Review. Neurocrit Care 2015;23(02):292-304

15 Waziri A, Fusco D, Mayer SA, McKhann GM 2nd, Connolly ES Jr. Postoperative hydrocephalus in patients undergoing decompressive hemicraniectomy for ischemic or hemorrhagic stroke. Neurosurgery 2007 Sep;61(03):489-494. Doi: 10.1227/01. NEU.0000290894.85072.37

16 Kutty RK, Sreemathyamma SB, Sivanandapanicker J, et al. The conundrum of ventricular dilatations following decompressive craniectomy: Is ventriculoperitoneal shunt, the only panacea? J Neurosci Rural Pract 2018;9(02):232-239

17 De Bonis P, Pompucci A, Mangiola A, Rigante L, Anile C. Posttraumatic hydrocephalus after decompressive craniectomy: an underestimated risk factor. J Neurotrauma 2010;27(11): 1965-1970

18 Takeuchi S, Takasato Y, Masaoka H, et al. Hydrocephalus after decompressive craniectomy for hemispheric cerebral infarction. J Clin Neurosci 2013;20(03):377-382. Doi: 10.1016/j. jocn.2012.03.035

19 Shi SS, Zhang GL, Zeng T, Lin YF. Posttraumatic hydrocephalus associated with decompressive cranial defect in severe braininjured patients. Chin J Traumatol 2011;14(06):343-347

20 Beauchamp KM, Kashuk J, Moore EE, et al. Cranioplasty after postinjury decompressive craniectomy: is timing of the essence? J Trauma 2010;69(02):270-274

21 Singh S, Singh R, Jain K, Walia B. Cranioplasty following decompressive craniectomy - Analysis of complication rates and neurological outcomes: A single center study. Surg Neurol Int 2019; 10:142. Doi: 10.25259/SNI_29_2019

22 Tsang ACO, Hui VKH, Lui WM, Leung GKK. Complications of postcraniectomy cranioplasty: risk factor analysis and implications for treatment planning. J Clin Neurosci 2015;22(05):834-837. Doi: $10.1016 /$ j.jocn.2014.11.021

23 Iaccarino C, Kolias AG, Roumy LG, Fountas K, Adeleye AO. Cranioplasty Following Decompressive Craniectomy. Front Neurol 2020; 10:1357. Doi: 10.3389/fneur.2019.01357

24 De Cola MC, Corallo F, Pria D, Lo Buono V, Calabrò RS. Timing for cranioplasty to improve neurological outcome: A systematic review. Brain Behav 2018;8(11):e01106. Doi: 10.1002/brb3.1106

25 Pachatouridis D, Alexiou GA, Zigouris A, et al. Management of hydrocephalus after decompressive craniectomy. Turk Neurosurg 2014;24(06):855-858

26 Kolias AG, Kirkpatrick PJ, Hutchinson PJ. Decompressive craniectomy: past, present and future. Nat Rev Neurol 2013;9(07): 405-415. Doi: 10.1038/nrneurol.2013.106

27 Kakar V, Nagaria J, John Kirkpatrick P. The current status of decompressive craniectomy. $\mathrm{Br} \mathrm{J}$ Neurosurg 2009;23(02): 147-157

28 Mustroph CM, Malcolm JG, Rindler RS, et al. Cranioplasty Infection and Resorption Are Associated with the Presence of a Ventriculoperitoneal Shunt: A Systematic Review and MetaAnalysis. World Neurosurg 2017;103:686-693. Doi: 10.1016/j. wneu.2017.04.066

29 Heo J, Park SQ Cho SJ, Chang JC, Park HK. Evaluation of simultaneous cranioplasty and ventriculoperitoneal shunt procedures. J Neurosurg 2014;121(02):313-318

30 Yang XF, Wang H, Wen L, Huang X, Li G, Gong JB. The safety of simultaneous cranioplasty and shunt implantation. Brain Inj 2017;31(12):1651-1655

31 Jung YT, Lee SP, Cho JI. An Improved One-Stage Operation of Cranioplasty and Ventriculoperitoneal Shunt in Patient with Hydrocephalus and Large Cranial Defect. Korean J Neurotrauma 2015;11(02):93-99

32 Oh CH, Park CO, Hyun DK, Park HC, Yoon SH. Comparative study of outcomes between shunting after cranioplasty and in cranioplasty after shunting in large concave flaccid cranial defect with hydrocephalus. J Korean Neurosurg Soc 2008;44 (04):211-216

33 Li G, Wen L, Zhan RY, Shen F, Yang XF, Fu WM. Cranioplasty for patients developing large cranial defects combined with posttraumatic hydrocephalus after head trauma. Brain Inj 2008;22 (04):333-337

34 Lin BJ, Chou KN, Feng SW, Ju DT, Ma HI, Hueng DY. Role of postdecompressive hydrocephalus in patients with malignant cerebral infarction. Turk Neurosurg 2015;25(05):742-748. Doi: 10.5137/1019-5149.JTN.11345-14.1 